\title{
Perceptions and economic losses from locoweed in north- eastern New Mexico
}

\author{
L. ALLEN TORELL, LES P. OWEN, KIRK C. MCDANIEL, AND DAVID GRAHAM
}

Authors are professor and research associate, Department of Agr. Econ. and Agr. Business, New Mexico State University, Las Cruces, N.M. 88003; profes sor, Department of Animal and Range Sciences, New Mexico State University, Las Cruces, N.M. 88003; Union County Extension Agent, New Mexico State University, Clayton, N.M. 88415.

Abstract

Livestock producers and others knowledgeable about the locoweed problem in northeastern New Mexico were surveyed to obtain the production information needed to estimate economic losses from locoweed (Oxytropis/Astragalus) poisoning. A partial budgeting approach was used to estimate economic losses based on animal performance differences with increasing levels of poisoning. With current production costs and 1990-96 average beef prices, annual locoweed poisoning losses were estimated to be $\$ 75$ head $^{-1}$ for moderately poisoned animals, and $\$ 282$ head $^{-1}$ for severely poisoned animals. The most common locoweed management strategy used by northeastern New Mexico ranchers was to move animals observed eating locoweed into locoweed-free areas. Rehabilitation of these animals for an extended period before sale was found to decrease economic loss relative to immediate sale. Moderately and severely poisoned animals that are rehabilitated were estimated to gain $14 \%$ and $29 \%$ less than non-intoxicated animals. Other management options including chemical locoweed control, fencing, and locoweed aversion were found to be economically justified when relatively high locoweed infestations are anticipated.

Key Words: Poisonous plants, woolly locoweed, Astragulus mol lissimus Torr. var mollissimus, white locoweed, Oxytropis sericea (Nutt.), weed control, grazing management

Poisoning from locoweeds (Astragalus spp. and Oxytropis spp.) cause major economic losses to the livestock industry in the western United States (James et al. 1999). Prolonged consumption of Astragalus and Oxytropis species causes animals to become lethargic and emaciated, and subject to chronic illness and possible death. Economic losses from locoweed include diminished reproductive performance, increased death losses, poor animal health, and reduced weights and sale prices. The magnitude of economic loss depends on the degree of intoxication and the proportion of a herd that is affected by the poisonous plant. The propensity to graze locoweed varies among animals, as some will occasionally eat the plant, while others will develop a preference for locoweed and become chronic eaters (Ralphs et al. 1993).

In this study we examine how locoweed poisoning and the actions taken to rehabilitate animals and minimize losses affect

This research was supported in part by the USDA/CSREES and the New Mexico Agricultural Experiment Station, New Mexico State University, Las Cruces, N.M.

Manuscript accepted 12 Nov. 1999

\section{Resumen}

El problema de la intoxicación con hierba loca (Oxytropis/Astragalus) fué estudiado a través de datos obtenidos entre productores de ganado y otros expertos del Nordeste de Nuevo Mexico con la finalidad de obtener la información necesaria para estimar las pérdidas económicas ocasionadas por éste problema en novillos de carne. Un enfoque parcial de presupuestos fué utilizado para estimar las pérdidas económicas tomando en cuenta las diferencias de la eficiencia animal al incrementarse los niveles de intoxicación. Considerando costos de producción reales y precios promedio de 1990 a 1996, para ganado de carne, las pérdidas económicas anuales por intoxicación con hierba loca fueron estimadas en $\$ 75$ por cabeza para animales moderadamente intoxicados y $\$ \mathbf{2 8 2}$ por cabeza para animales severamente intoxicados.Se encontró que la rehabilitación de estos animales, por un período prolongado hasta antes de su venta, disminuye las pérdidas económicas en relación a que si éstos hubieran sido vendidos inmediatamente. A los animales con moderada y severa intoxicación que son rehabilitados se les estimó una pérdida de $14 \%$ y $29 \%$, respectivamente, en comparación a los animales no intoxicados. La estrategia de manejo generalmente usada por los productores del Nordeste de Nuevo Mexico fue a cambiar los animales que se observaron comiendo hierba loca a otra área no infestada con dicha hierba. Otras opciones de manejo incluyendo el control químico, cercado y aversión al consumo de hierba loca fueron encontradas económicamente justificadas cuando son previstas altas infestaciones de hierba loca.

the economics of yearling cattle operations in northeastern New Mexico. In this region, yearling stocker operations are diverse and use widely different production strategies, including retaining yearlings calves, annual purchase of yearling animals, grazing on leased versus owned pasture, and with many different arrangements for the daily care of cattle (Torell et al. 1998). The grazing season typically starts late March to early May and runs through mid-October. Problems resulting from locoweed consumption may occur at any time during this grazing season.

To determine the extent of the region's locoweed problem and to define alternative grazing strategies that might reduce impacts from locoweed, personal interviews and meetings were held with livestock producers and others knowledgeable about managing locoweed problems, including how to deal with locoweed poisoned animals and how to minimize economic losses from the weed. Our objectives were to: 1) evaluate the economic effectiveness of alternative locoweed management strategies based on 
information provided by northeastern New Mexico livestock producers, and 2) determine how much could be spent on added locoweed management while still maintaining a positive benefit/cost ratio for the investment.

\section{Methods}

\section{Defining Locoweed Symptoms}

Successful recovery from locoweed poisoning depends on recognizing the disease early and preventing animals from eating more plants. Clinical symptoms of locoism include a lack of coordination, visual impairment, depression, unpredictable behavior, and emaciation (Allison 1991). Field definition of locoism is imprecise and detection largely depends on the experience of the observer (Stegelmeir et al. 1996). Visual cues are usually used to broadly categorize the extent to which an animal may be intoxicated (Allison 1991). For this study, we use a none categorization to describe animals with no visual signs of locoweed poisoning, such as those having a healthy, thrifty appearance with a bright hair coat. Moderately poisoned animals were defined to be cattle showing early signs of dead and dull hair, eyes with a glazed and clouded look, and animals not yet exhibiting symptoms of trembling or obvious weight loss. By contrast, severely poisoned animals were considered to clearly have an unhealthy appearance. At this stage animals tremble when startled, they cannot focus their eyes, the hair coat is shaggy and dead, and weight loss is obvious compared to other non-eating locoweed cattle in the herd.

\section{Estimating effects from locoweed poi- soning}

Information needed to estimate locoweed poisoning losses was largely obtained from personal interviews and group panel meetings with northeastern New Mexico livestock producers. Cooperators were surveyed in summer 1997 and included 17 northeastern New Mexico ranchers, 1 feedlot operator, 1 veterinarian, 2 County Extension agents, and a manager from the Clayton, N. M. livestock auction. All had first hand experience with locoweed poisoning and had dealt with the poisoning problem in various ways. Interviewees were asked specific survey questions, but during the interviews there was also open discussion about the symptoms, losses and management of locoweed. Those interviewed compared production differences between none, moderate and severely intoxicated yearling cattle. They provided their best estimates of how average daily gain (ADG) might vary over the grazing season; how common the locoweed problem is in their area; how long symptoms of locoweed poisoning might last; how much death loss occurs; how animals respond to a detoxification period; and what management strategies might best be employed to minimize economic losses. They were also asked to estimate how rates of gain and sale prices could be expected to change once animals were removed from locoweed infested areas.

In addition to the general observations from northeastern New Mexico producers, information for our economic analysis was also obtained from grazing trails conducted in 1996 and 1997 near Clayton, N.M. (Owen et al. 1999). In these grazing trails 2 groups of cooperator-owned cattle were monitored for weight gain and frequency of locoweed poisoning. As described in more detail by Owen (1998) and Owen et al. (1999), producer animals were monitored to determine differences in ADG between cattle poisoned and not poisoned by locoweed, and to investigate poisoning and performance differences between steers versus heifers, by whether cattle where imported from out-of-state versus those locally purchased, by grazing strategy, and by the amount of locoweed in pastures where cattle grazed. These studies indicated that yearlings (both steers and heifers) not suffering from locoweed poisoning ${ }^{1}$ can be expected to gain about 0.70 to $0.87 \mathrm{~kg}^{-1}$ head $^{-1}$ day $^{-1}$. Yearling steers and heifers with visual signs of locoism gained an average $0.35 \mathrm{~kg}^{-1}$ head $^{-1}$ day $^{-1}$.

In a separate grazing trial also conducted in 1997 near Clayton, N.M., Ralphs et al. reported yearling steers not eating locoweed gained $0.71( \pm 0.02) \mathrm{kg}^{-1}$ head ${ }^{-1}$ day $^{-1}$. They reported ADG for locoweed intoxicated animals to average 0.44 $( \pm 0.04) \mathrm{kg}^{-1}$ head $^{-1} \mathrm{day}^{-1}$. The estimated range in measured rates of gain reported from the Owen (1998) and Ralphs et al. (2000) studies were consistent with experiences expressed by those participating in the interviews and panel meetings. Survey participants also detailed how ADG typically varies over the grazing season and how rates of gain increase once animals are removed from locoweed infested areas.

\footnotetext{
${ }^{1}$ These animals were apparently not consuming locoweed because they showed no visual signs of poisoning or in other cases they had been grazing a locoweed free pasture. Measures of data dispersion and individual animal weights were not recorded.
}

This information was used to define expected ADG over the grazing season for the none, moderate, and severe locoweed poisoning categorizations (Fig. 1).

\section{Defining Management Alternatives}

Various strategies have been devised from practical and research experience to minimize locoweed poisoning and to rehabilitate animals once they are intoxicated. For this study, we compared 3 management alternatives that have been employed by northeastern New Mexico ranchers. The first alternative, called loco and pull, requires that cattle be checked frequently and when an animal is observed eating locoweed it is immediately moved from the herd to a separate locoweed-free pasture (Allison and Graham 1999). Detection and roundup delays often occur, thus some animals may already be intoxicated and show definite signs of poisoning when removed.

A second potential management alternative, called delayed grazing, was proposed by Ralphs et al. (1993), and prevents grazing in locoweed infested pastures until dominant grasses, such as blue grama (Bouteloua gracilis (H.B.K.) Lag. ex Griffiths), are actively growing. Typically, in northeastern New Mexico, blue grama initiates green up in late May or June, so under this alternative the start of the grazing season is delayed until this time. This alternative, as well as the loco and pull alternative, obviously require that locoweed-free areas be available. If a locoweed-free area is not available then ranchers must decide if leasing locoweedfree land, feeding animals in a drylot, or immediately selling animals is more practical than grazing a locoweed infested pasture and risking poisoning. With adequate financing, planning and timing, chemical control or fencing could be used to create locoweed-free pastures (McDaniel 1996).

We do not provide an economic evaluation of the delayed grazing alternative because more research is needed to clearly determine the willingness (or lack thereof) of cattle to eat locoweed when the start of the grazing season is delayed until green grasses are present. We do draw broad estimates about the feasibility of delayed grazing based on similarities with other management alternatives.

The third management alternative evaluated, called locoweed aversion, has recently been proposed by Ralphs et al. et al.. Under this alternative cattle are fasted overnight and then given an emetic (lithium chloride) the next morning with freshly chopped locoweed (or other poisonous 
plant) to cause gastro-intestinal distress and thereby discourage animals from eating the plant. In our analysis we considered the costs of giving the emetic and monitoring the cattle under experimental conditions (Michael Ralphs and David Graham, personal communications). Similar labor requirements and costs were assumed for commercial herds.

\section{Economic Model Definition}

The economic model, which is Lotus 1$2-3^{\mathrm{TM}}$ spreadsheet-based, consists of 3 major components. First, the rate of gain for a herd of yearling cattle carried over a specified grazing season and with a defined level of locoweed poisoning is given as user input. Figure 1 details the daily gains and animal weights defined in the model. Animal weights are computed for each day of the grazing season based on specific assumptions about purchase date, degree of locoweed poisoning, and timing of detection and rehabilitation (Table 1). The ADG definitions were based on estimates provided from the producer surveys and grazing trials conducted by Owen (1998) and Ralphs et al. 2000.

The number of livestock eating and poisoned by locoweed is obviously a very important determinant of economic impacts from locoweed. Based on estimates provided by livestock producers, in a typical year about $68 \%$ of yearlings could be expected not to consume large enough quantities of locoweed to become intoxicated, $25 \%$ would become moderately intoxicated, and $7 \%$ would be severely poisoned. While we assumed this break down for our analysis, it must be emphasized that the proportion of a herd poisoned by locoweed is highly variable from year-to-year and from ranch-to-ranch and that these averages are merely a reasonable estimate of expected intoxication levels.

The second model component is a livestock pricing model that estimates purchase and sale prices for cattle with selected characteristics and sale weights. This price adjustment is necessary because sale weights and sale prices will be different for different levels of locoweed poisoning. Livestock purchase and sale prices were estimated using a reduced form of a beef pricing model developed by Sartwelle et al. (1995, 1996a, and 1996b). Parameters from the pricing model were used to adjust prices for sale weight (w) differences. Base prices were set using 1990-96 average prices from livestock auctions in Clovis, N.M. Purchase price was based on $204 \mathrm{~kg}$ steer calves $\left(\right.$ Base $\left._{\mathrm{c}}=\$ 1.98 \mathrm{~kg}^{-1}\right)$ and sale price on $295 \mathrm{~kg}$ feeder steers
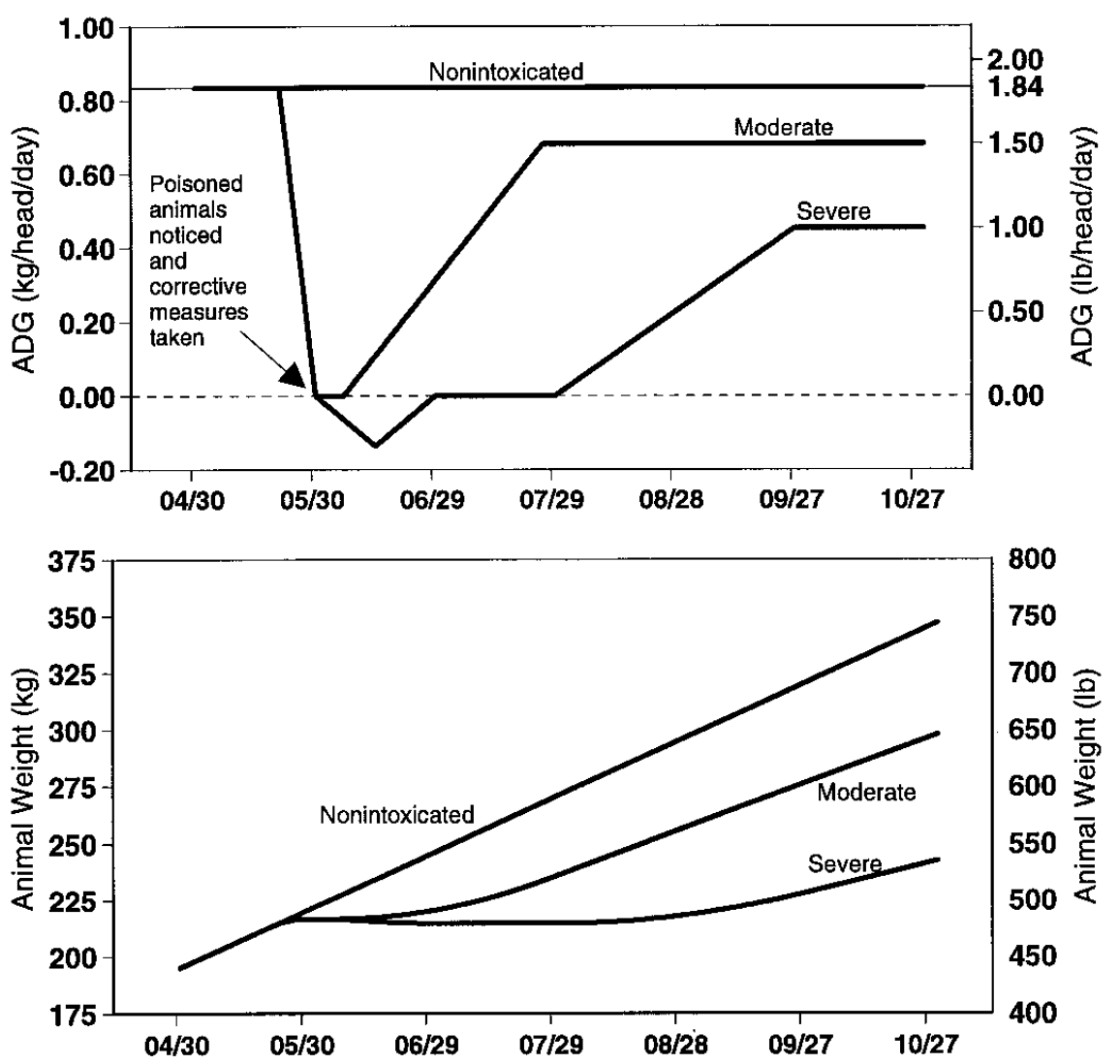

Fig. 1. Expected variations in ADG and animal weight over the grazing season.

(Base $\left._{\mathrm{f}}=\$ 1.72 \mathrm{~kg}^{-1}\right)$. Using the reduced Sartwelle price model, equations were developed for both purchase and sale prices as follows: economic returns are reduced because some animals are poisoned by locoweed.

Other management options are compared to loco and pull to determine their
$\mathrm{P}_{\mathrm{p}}=$ Base $_{\mathrm{c}}-1.77 \times 10^{-3}(\mathrm{w}-204)-1.46 \times 10^{-6}\left(\mathrm{w}^{2}-204^{2}\right)$

$\mathrm{P}_{\mathrm{s} 1}=$ Base $_{\mathrm{f}}-7.29 \times 10^{-5}(\mathrm{w}-295)-7.29 \times 10^{-7}\left(\mathrm{w}^{2}-295^{2}\right)$

$\mathrm{P}_{\mathrm{s} 2}=$ Base $_{\mathrm{c}}-4.41 \times 10^{-3}(\mathrm{w}-204)+1.46 \times 10^{-6}\left(\mathrm{w}^{2}-204^{2}\right)$
Steer Purchase Price

Sale Price, Weight $\geq 272 \mathrm{~kg}$ Sale Price. Weight $<272 \mathrm{~kg}$
The third model component generates cost and return estimates for a specified management scenario. The economic analysis was conducted with specific assumptions about production expenses, labor requirements, prices and rehabilitation costs by intoxification category (none, moderate, and severe). Parameters of the economic model were then altered to generate cost and return estimates for alternative management scenarios.

Loco and pull management was first compared to a situation in which no locoism occurred. In this comparison, differences in sale weights, sale prices, and rehabilitation costs were computed for each of the 3 intoxication categories. This provided a direct estimate of economic losses to locoweed by intoxication category, and an estimate of how much overall economic advantage or disadvantage. Loco and pull management was used as the base for comparison because, according to the producer survey, it is the alternative most widely practiced. Under the loco and pull alternative a livestock operator may decide to rehabilitate an animal in a locoweed-free area or choose to sell the animal immediately after it is identified.

Specific assumptions were made about the timing of diagnosis, rehabilitation and sale of animals (Table 1). It was assumed that poisoned animals would be identified 30 days after being placed in a locoweedinfested pasture. With the ADG definitions used in the economic model (Fig. 1), animals purchased at $195 \mathrm{~kg}$ would weigh approximately $218 \mathrm{~kg}$ after 30 days of grazing. Selling the animals at this early date saves the producer additional feed 
Table 1. Economic model definition for loco and pull management.

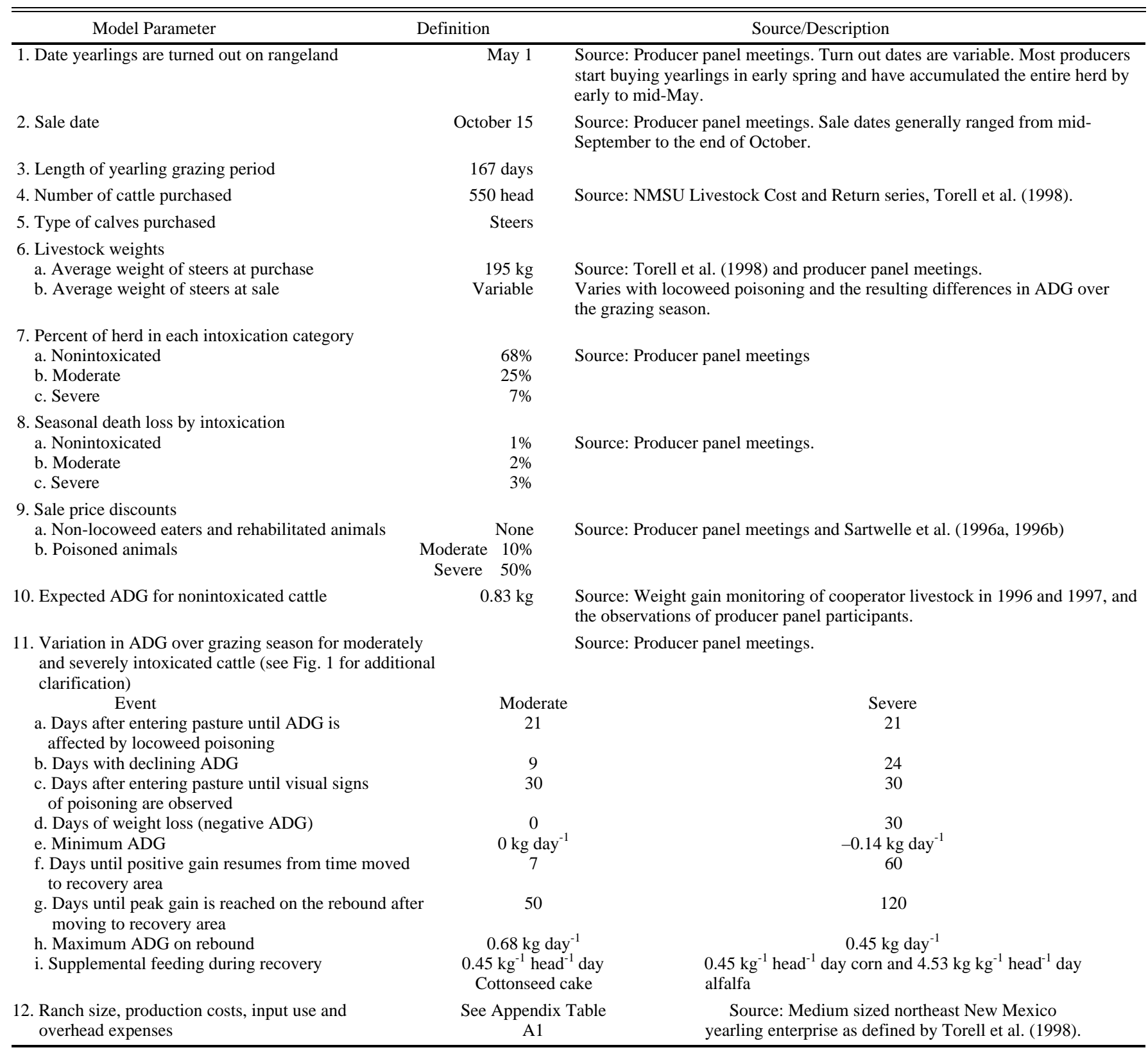

costs for rehabilitation. However, if light weight animals are visibly intoxicated they will have a significant price discount.

In the economic analysis, no price discount was used for animals rehabilitated before sale, but a $10 \%$ price reduction was used for moderately intoxicated cattle and a $50 \%$ reduction for severely poisoned cattle that are immediately sold without rehabilitation. This is similar to price reductions observed in Kansas for health problems that are also commonly associated with locoweed poisoning (Sartwelle et al. 1996a,1996b).

To evaluate the locoweed aversion alternative, it was assumed that naïve cattle (i.e. imported cattle or animals not familiar with locoweed) would be purchased and the aversion treatment would be $100 \%$ successful. Ralphs et al. 2000 reported this high success rate with aversion trials conducted in 1996 and 1997 with naïve cattle. The cost associated with the aversion treatment was estimated to be $\$ 7$ head $^{-1}$ based on the time and input required to conduct the aversion treatment in research trials. This cost includes a lithium chloride treatment, labor for harvesting fresh locoweed for the aversion, and monitoring cattle to assure successful aversion.

\section{Results}

\section{Producer Observations}

Questions posed from the producer survey and subsequent discussions with livestock producers in northeastern New Mexico provided insight into the locoweed problem and identified many areas in need of future research. All interviewees reported having locoweed problems in the past, but this was expected because this was part of the selection criterion for those interviewed. Producers reported the highest incidences of poisoning in spring and fall when locoweed was the dominant 
green forage, rather than mid-summer when warm season grasses were actively growing. They reported on average that locoweed poisoned yearlings could be expected to have end-of-season weight losses from 23 to $68 \mathrm{~kg} \mathrm{head}^{-1}$ depending on the degree of locoweed intoxication, compared to non-poisoned animals. It was agreed by all participants that incidences of locoweed poisoning are widely variable between locations and years.

Supplementation with a high-energy feedstuff and removal of animals to a locoweed-free area was felt to be necessary for poisoning recovery. Consequently, most producers interviewed reported they try to immediately move locoweed intoxicated animals to recovery areas. While in a recovery area (which varied from locoweed-free pastures to holding pens and corrals), a variety of supplementation treatments were used to expedite the recovery process. Reported treatments included feeding a combination of protein block, alfalfa hay and grain with additional vitamin/mineral supplements.

Only one producer preferred to immediately sell animals after visual signs of locoweed poisoning were observed. Other producers felt that keeping the animals for an extended recovery period was more economical because the reduced sale weight from immediate sale, and especially the price discount for intoxicated animals, was too great.

Depending on the degree of intoxication, producers reported reduced sale prices from $10 \%$ to $85 \%$ for affected animals with visible poisoning symptoms. Interviewees generally agreed that local buyers were knowledgeable about locoweed poisoning and they could readily identify cattle that had been eating the weed. Livestock producers noted that animals, even severely poisoned animals, could be rehabilitated to where the poisoning was no longer visibly apparent and that this would eliminate the price discount.

Research has shown reproductive effects will be greatly reduced once animals are removed from locoweed diets (Stegelmeir et al. 1996). All interviewees reported that reproductive performance should eventually improve following an extended recovery period, but most believed that longterm damage does occur and animal performance never completely recovers. All but one of the producers reported that they later sell rehabilitated animals, including brood stock, because they do not believe the cattle will ever completely recover from locoism.

Livestock producers concurred that

Table 2. Economic losses from locoweed poisoning for yearling stocker operations in northeastern New Mexico.

\begin{tabular}{lcc}
\hline \hline & Moderate & Severe \\
\hline & $----(\$ /$ head eating locoweed)---- \\
Lost gross revenue from diminished livestock performance & $\$ 68$ & $\$ 184$ \\
Added costs for rehabilitating locoweed-poisoned animals & $\frac{7}{75}$ & $\frac{98}{282}$ \\
Net difference in ranch income & 75 & 282 \\
\hline
\end{tabular}

Note: The comparisons for moderate and severe locoweed poisoning are made relative to nonintoxicated cattle. Average 1990-96 beef prices and 1996 production costs are considered in the analysis. See Appendix Table A1 for a more detailed listing of production and economic differences.

proper management is the key to minimizing problems associated with locoweed. Every producer interviewed believed that social facilitation ${ }^{2}$ (Ralphs et al. 1994) plays a major role in causing cattle to begin eating locoweed. For this reason, the loco and pull strategy was used by many of those interviewed to prevent habitual eaters from influencing naïve animals. Time spent monitoring cattle varied between the interviewees, as did the degree of success with this management strategy.

None of those surveyed indicated they use delayed grazing as outlined by Ralphs et al. (1993). Primary reasons reported for not employing this approach was that grazing deferment was perceived to be too costly, locoweed-free pastures were not available, and delayed grazing complicated contractual obligations for leased yearlings. However, producers generally did not disagree with the concept of delayed grazing.

All producer panel participants recognized that significant economic losses occur after cattle become intoxicated by locoweed. Yet, when asked to give their perception about how widespread and severe the locoweed problem is in northeastern New Mexico, producer responses ranged from one individual who believed that it was "not a widespread and persistent problem" because management practices that producers have adopted satisfactorily deal with the problem, to the more common belief that "locoweed presents the most severe economic problem that producers in the area are faced with."

\section{Economic Losses and Management of Locoweed}

Economic losses from locoweed poisoning are substantial and include both reduced sales value and increased production costs. Given the parameter specifications used in the economic analysis (Table 1 ), locoweed poisoning in northeastern

\footnotetext{
${ }^{2}$ Social facilitation is defined as the initiation of a particular response as the result of observing others engage in that behavior (Galef 1988).
}

New Mexico was estimated to reduce net ranch income from $\$ 75$ to $\$ 282$ per head depending on whether the yearling steers were moderately or severely intoxicated (Table 2).

Feeding practices adopted and the extent to which animals are intoxicated influences rehabilitation costs. Moderately intoxicated steers were assumed to be supplemented with $0.45 \mathrm{~kg}_{\text {head }}{ }^{-1}$ day $^{-1}$ cottonseed cake for 57 days and this added $\$ 7$ head $^{-1}$ in feed costs. Severely intoxicated cattle supplemented with $4.53 \mathrm{~kg}^{-1} \mathrm{hed}^{-1}$ day $^{-1}$ of alfalfa and $0.45 \mathrm{~kg} \mathrm{head}^{-1}$ day $^{-1}$ of corn for 120 days in the recovery area added $\$ 98$ head $^{-1}$ in feed cost. Sale weights were still reduced after supplementation and recovery. Given the defined differences in ADG (Fig. 1), average sale weights with loco and pull management were estimated to be $334 \mathrm{~kg}$ for non-intoxicated animals, $288 \mathrm{~kg}$ for moderately poisoned animals, and $236 \mathrm{~kg}$ for severely poisoned animals (Appendix Table A1).

Immediate sale of poisoned animals results in significantly higher economic losses than rehabilitating animals with loco and pull management (Table 3). With 1990-96 average beef prices and with the price discounts assumed for intoxicated cattle, the economic loss per animal from immediate sale was estimated to increase by $\$ 103$ head $^{-1}$ and $\$ 68$ head $^{-1}$ for moderately and severely intoxicated animals, respectively. This comparison is made relative to animals rehabilitated before sale using loco and pull management.

The economic penalty for immediately selling a severely intoxicated animal is less than a moderately intoxicated animal because the recovery period is longer, supplemental feed costs are higher and thus rehabilitation costs are higher. When the relative number of moderately and severely poisoned animals on a ranch are considered (assumed to be $25 \%$ and $7 \%$ of the herd, respectively in this analysis) the weighted average value of healing intoxicated animals (versus immediately selling them) is estimated to be $\$ 95.35$ head $^{-1}$.

Having locoweed-free pastures is crucial 
Table 3. Economic losses associated with immediate sale of yearlings poisoned by locoweed.

\begin{tabular}{|c|c|c|c|c|c|c|}
\hline & \multicolumn{2}{|c|}{$\begin{array}{l}\text { Loco and pull } \\
\text { Management }\end{array}$} & \multicolumn{2}{|c|}{$\begin{array}{c}\text { Immediate } \\
\text { Sale }\end{array}$} & \multicolumn{2}{|c|}{$\begin{array}{l}\text { Added Loss from } \\
\text { Immediate Sale }\end{array}$} \\
\hline & Moderate & Severe & Moderate & Severe & Moderate & Severe \\
\hline & & & ead eating & weed) & & - \\
\hline Gross returns & $\$ 486$ & $\$ 370$ & $\$ 370$ & $\$ 204$ & $\$ 110$ & $\$ 166$ \\
\hline Total costs & 497 & 587 & 490 & 490 & -7 & -98 \\
\hline Net ranch income & -11 & -217 & -114 & -286 & 103 & 68 \\
\hline
\end{tabular}

to successfully implementing loco and pull and delayed grazing management. The $\$ 95.35$ head $^{-1}$ added value from rehabilitating animals can be used to estimate the economic value of having this locoweed-free area if immediate sale is the only other option. The value of rehabilitation can be converted to a $\$ \mathrm{ha}^{-1}$ value by considering the standard stocking rate allowance used in northeastern $\mathrm{New}$ Mexico of 6.1 ha yearling ${ }^{-1}$ for a 6 month grazing season (Stuckey and Henderson 1969). The rehabilitation period assumed in our analysis was $4 \frac{1}{2}$ months, thus the equivalent grazing allowance for this shorter time would be 4.86 ha head ${ }^{-1}$. The $\$ 95.35$ head $^{-1}$ rehabilitation value means that the estimated value of a locoweed free area is $\$ 19.62 \mathrm{ha}^{-1}\left(\$ 95.35 \mathrm{head}^{-1} / 4.86\right.$ ha head $\left.^{-1}\right)$. This assumes that locoweed-free pastures are or can be made available on the ranch and poisoned animals can be moved to these areas, fed additional supplements, and rehabilitated before sale in late fall.

If a locoweed-free area does not exist, the estimated $\$ 19.62 \mathrm{ha}^{-1}$ added loss from forced immediate sale is the amount one can afford to spend creating a locoweedfree area. With costs ranging from $\$ 35$ to $\$ 40 \mathrm{ha}^{-1}$ for chemical and aerial application costs (McDaniel 1996), a herbicide treatment could be economically feasible provided the area remains loco-free for at least 2 years. Under these circumstances, a successful spray treatment made before the start of the grazing season and lasting 1 additional year would yield a $12.6 \%$ rate of return on investment. Conventional and electric fencing can also be used to preclude grazing of localized problem areas.

Leasing locoweed-free rangeland is another option. Considering forage value to be the amount of added loss from forced sale of intoxicated animals, a producer could afford to spend about $\$ 23$ month $^{-1}$ head $^{-1}$ to lease locoweed-free forage for moderately poisoned animals and $\$ 15$ month $^{-1}$ head $^{-1}$ for severely poisoned animals (i.e. $\$ 103 / 41 / 2$ months $=\$ 22.89$ month $^{-1}$ head $^{-1}$ for moderately poisoned animals, and $\$ 68 / 41 / 2$ months $=\$ 15.11$ month $^{-1}$ head $^{-1}$ for severely poisoned ani- mals). By comparison, average rangeland lease rates in the 11 western states were $\$ 11.80$ head $^{-1}$ during 1997 (USDA-NASS 1998).

Spending $\$ 7$ head $^{-1}$ to establish an aversion for eating locoweed was estimated to result in a net economic benefit of $\$ 32$ head $^{-1}$ (Table 4). This results largely from the added livestock sales from averted animals, but an estimated $\$ 2$ head $^{-1}$ cost sav ings also results. This savings occurs because the cost of the aversion was estimated to be $\$ 2$ head $^{-1}$ less than supplemental feed costs that would have been required to rehabilitate intoxicated animals without the aversion. This will be highly variable, however, and will depend on the cost of supplemental feeds and how many animals would have been poisoned without the aversion treatment. We assumed $25 \%$ and $7 \%$ of the herd would have been moderately and severely poisoned without the aversion treatment. The improved performance of this part of the herd economically justifies the aversion.

As a sensitivity analysis, the proportion of the herd potentially affected by locoweed was decreased from the assumed levels defined above, while keeping the relative number of moderately and severely poisoned animals the same. This was done to determine at what point the aver sion treatment and loco and pull management would be economically equivalent. It was estimated that if more than $9 \%$ of the herd $(7 \%$ moderate and $2 \%$ severe) would have been poisoned by locoweed without the aversion then the locoweed aversion treatment would be superior to the loco and pull management strategy. At levels below this point, the cost of averting the

Table 4. Economic benefits of conditioned feed aversion.

\begin{tabular}{lccc}
\hline \hline & $\begin{array}{c}\text { Loco and pull } \\
\text { Management }\end{array}$ & Feed Aversion & $\begin{array}{c}\text { Benefit of } \\
\text { Aversion }\end{array}$ \\
\hline Gross returns & $-\ldots-1$ & 555 & 31 \\
Supplemental feed costs for & -9 & 0 & 9 \\
rehabilitation & 0 & -7 & -7 \\
Cost of aversion & 26 & 58 & 32 \\
Net ranch income & & & \\
\hline
\end{tabular}

entire herd would be greater than the production losses realized, given the relatively small number of animals that would have been poisoned without the aversion. The practical problem is knowing how many animals would be poisoned without the aversion treatment.

\section{Discussion and Conclusions}

Locoweed poisoning has a substantial economic impact on yearling operations. This economic loss is extremely variable from year-to-year and ranch-to-ranch. Some of this variability can be attributed to the cyclical occurrence of locoweeds, especially woolly locoweed (Astragalus mollissimus Torr. var mollissimus). Weather patterns, insects, and type and intensity of grazing management contribute to this variability (Pomerinke et al. 1995, Ralphs et al. 1993).

The unpredictable nature of locoweed infestation makes the determination of what proportion of livestock will become intoxicated highly complex. Further, projecting economic losses is difficult because there is no straightforward management approach available to deal with the poisoning problem. Strategies that have been used or considered in research generally attempt to prevent animals from eating locoweed, or they limit grazing use of locoweed infested areas.

Northeastern New Mexico ranchers have largely adopted the loco and pull management strategy. However, how efficient producers are in selecting and removing livestock from locoweed-infested areas is widely variable. Some leave animals in a pasture until visible signs of poisoning are apparent while others are less willing to allow animals to continue eating the poisonous plant. Regardless of when livestock are removed, it is important to have locoweed-free areas in which to rehabilitate animals. According to our partial budgeting assessment, it is generally profitable to invest in weed control or fencing to create and maintain needed locoweed-free areas. 
Research experience with livestock aversion has been successful in training animals not to eat locoweed (Ralphs et al. 2000). However, further practical experiences and commercial application is needed to refine the procedure and further define costs. Another potential and similar management alternative where attempts are made to keep animals from eating locoweed is delayed grazing. While not specifically considered and budgeted here, delayed grazing could also be an economically feasible way to minimize losses from locoweed. As reported by Owen et al. (1999), monitoring and weighing of producer cattle during 1997 indicated that animal performance for delayed grazing was similar if not improved over that of the aversion treatment. The economic benefit of delayed grazing could then potentially be similar to the $\$ 32 \mathrm{ha}^{-1}$ estimated for the aversion treatment. The cost of the aversion would be spared with delayed grazing, but other expenses to create and maintain locoweed-free areas would be expected. As more and more effort is required to create locoweed free areas the net economic benefit of delayed grazing and loco and pull management would be diminished. However, with substantial improvement in livestock gains, spraying or fencing selected areas to create locoweed free areas for spring grazing may be economically justified. More grazing trials replicated across years are needed to further evaluate the feasibility of the delayed grazing treatment.

In this study, definition of the locoweed economic model was based on cost and animal production differences estimated from surveys with knowledgeable livestock producers in northeastern New Mexico, and from limited grazing trials that studied production differences (Owen 1998, Ralphs et al. 2000). To better estimate economic losses from locoweed, further animal research is needed to determine how animal performance is affected at different stages of locoweed poisoning. Reproductive impacts of locoweed poisoning should be investigated. Further research is also needed to develop indicators defining the extent of locoweed intoxication for particular animals. Many alternative management strategies have the potential for reducing economic losses from locoweed and even more options would be available if locoweed-eating animals could be identified earlier.

\section{Literature Cited}

Allison, C.D. 1991. Livestock-poisoning plants of New Mexico rangelands. New Mexico State Univ. Coop. Ext. Serv. Circ. 531.

Allison, C.D. and J.D. Graham. 1999. Reducing locoism with management decisions. pp. 64-66. In: T.M. Sterling and D.C. Thompson (eds)., Locoweed research updates and highlights. New Mex. State Univ. Agr. Exp. Sta. Rep. 730.

Galef, B.G., Jr. 1988. Imitation in animals: history, definition, and interpretation of data from the psychological laboratory. pp. 3-21. In: T.R. Zentall and B.G. Galef, Jr. (eds.), Social learning psychological and biological perspectives. Lawrence Erlbaum Assoc. Publ., Hillsdale, N.J.

James, L.F., K.E. Panter, B.L. Stegelmeier, M.H. Ralphs, J.A. Pfister, and D.R. Gardner. 1999. Astragalus and Oxytropis poison livestock with different toxins. pp. 10-11. In: T.M. Sterling and D.C. Thompson (eds)., Locoweed research updates and highlights. New Mex. State Univ. Agr. Exp. Sta. Rep. 730

McDaniel, K.C. 1996. Locoweed herbicide control program. pp. 11-15. In: Locoweed and broom snakeweed research update. New Mexico State Univ. Agr. Exp. Sta. and Coop. Ext. Serv., Clayton Air Park Clayton, N.M.

Owen, L.P. 1998. Economic analysis of locoweed infested rangeland in northeastern New Mexico. Master's Thesis, New Mexico State Univ., Las Cruces, N.M.

Owen, L.P., L.A. Torell, J.D. Graham, and M.H. Ralphs. 1999. Degree of locoweed poisoning predicts yearling stocker performance. pp. 71-73. In: T.M. Sterling and D.C. Thompson (eds).,Locoweed research updates and highlights. New Mex. State Univ. Agr. Exp. Sta. Rep. 730.

Pomerinke, M.A., D.C. Thompson, and D.L. Clason. 1995. Bionomics of Cleonidius trivittatus (Coleoptera: Curculionidae): native biological control of purple locoweed (Rosales: Fabaceae). Environ. Entomol. 26:1696-1702.

Ralphs, M.H., D. Graham, and L.F. James. 1994. Social facilitation influences cattle to graze locoweed. J. Range Manage. 47:123-126.

Ralphs, M.H., D. Graham, L.F. James, and R.J. Molyneux. 1993. Seasonal grazing of locoweed by cattle in Northeastern New Mexico. J. Range Manage. 46:416-420.

Ralphs, M.H., G. Duff, D. Graham, L.F. James, and B.L. Stegelmeier. 2000. Impact of locoweed poisoning on grazing steer weight gains. J. Range Manage. 53:86-90.

Sartwelle, J.D., III, F. Brazle, M.R. Langemeier, J.R. Mintert, and T.C. Schroeder. 1995. Feeder cattle price differentials: how much do they change over time? Paper presented at the Southern Agr. Econ. Assoc. Meetings, 29 Jan. 1 Feb. 1995.
Sartwelle, J.D., III, F. Brazle, M.R. Langemeier, J.R. Mintert, and T.C. Schroeder. 1996a. Improving the value of your calf crop: the impact of selected characteristics on calf prices. MF-2142, Coop. Ext. Serv., Kansas State University.

Sartwelle, J.D., III, F. Brazle, M.R. Langemeier, J.R. Mintert, and T.C. Schroeder. 1996b. Buying and selling feeder cattle: the impact of selected characteristics on feeder cattle prices. MF-2162, Coop. Ext. Serv., Kansas State University.

Stegelmeier, B., L. James, K. Panter, J. Pfister, M. Ralphs. 1996. Effects of locoweed on reproduction in livestock. p. 8 . In: Locoweed and broom snakeweed research update. New Mexico State Univ. Agr. Exp. Sta. and Coop. Ext. Serv., Clayton Air Park Clayton, N.M.

Stuckey, H.R. and D.C. Henderson. 1969. Grazing capacities and selected factors affecting public land use. New Mexico State University, Agric. Exp. Sta. Research Report 158.

Torell, L.A., J.M. Hawkes, and T.D. Stromei. 1998. Range livestock cost and return estimates for New Mexico, 1996. New Mexico State Univ. Agr. Exp. Sta. Research Report 726.

U.S. Department of Agriculture, National Agricultural Statistics Service (USDANASS). 1998. Agricultural prices. PR13(98), Washington, D.C. 
Appendix table A1. Cost and return estimates for loco and pull management.

\begin{tabular}{|c|c|c|c|c|c|c|c|c|}
\hline \multirow[b]{2}{*}{ Number } & & & \multirow[t]{2}{*}{$\begin{array}{c}\text { Sale } \\
\text { Weight }\end{array}$} & \multirow{2}{*}{ Total } & \multicolumn{3}{|c|}{ Purchased } & \multirow{2}{*}{$\begin{array}{c}\text { Weighted } \\
\text { Average } \\
\end{array}$} \\
\hline & & & & & No Loco & Moderate Loco $\mathrm{S}$ & Severe Loco & \\
\hline & & $(\$ / \mathrm{Kg})$ & $(\mathrm{Kg})$ & $(\$)$ & (\$/Head) & & & \\
\hline \multicolumn{9}{|c|}{ I. GROSS RETURNS } \\
\hline 370 & Non-Loco Steers & $\$ 1.68$ & 334 & $\$ 207,244$ & $\$ 554.13$ & & & \\
\hline 135 & Moderate-Loco Steers & $\$ 1.72$ & 288 & $\$ 66,866$ & & $\$ 486.29$ & & \\
\hline \multirow[t]{3}{*}{37} & Severe-Loco Steers & $\$ 1.63$ & 236 & $\$ 14,238$ & & & $\$ 369.81$ & \\
\hline & Total & & & $\$ 288,348$ & 554.13 & 486.29 & 369.81 & 524.27 \\
\hline & & & \multicolumn{5}{|c|}{$\$ /$ Head Purchased } & \\
\hline $\begin{array}{l}\text { II. COS } \\
\text { A. V }\end{array}$ & $\begin{array}{l}\text { S } \\
\text { RIABLE COSTS }\end{array}$ & $\underline{\text { Unit }}$ & $\underline{\$ / \text { Unit }}$ & $\underline{\text { Total } \$}$ & $\underline{\text { No Loco }}$ & $\underline{\text { Moderate Loco }}$ & $\underline{\underline{0}} \underline{\text { Severe Loco }}$ & $\begin{array}{r}\text { Weighted } \\
\text { Average }\end{array}$ \\
\hline \multicolumn{9}{|c|}{ 1. Feed: } \\
\hline 26.5 & Purchased Hay & MT & 141 & 3,738 & 1.63 & 1.63 & 78.43 & 7.01 \\
\hline 0.9 & Grain & MT & 387 & 352 & 0.64 & 0.64 & 0.64 & 0.64 \\
\hline 2.0 & Corn & MT & 385 & 777 & 0.00 & 0.00 & 21.00 & 1.47 \\
\hline 3.5 & Cottonseed Cake & MT & 275 & 962 & 0.00 & 7.13 & 0.00 & 1.78 \\
\hline 7.0 & Protein Supplements & MT & 278 & 1,948 & 3.54 & 3.54 & 3.54 & 3.54 \\
\hline 1.8 & Salt & MT & 143 & 260 & 0.47 & 0.47 & 0.47 & 0.47 \\
\hline \multirow[t]{2}{*}{6.4} & Minerals & MT & 355 & 2,261 & 4.11 & 4.11 & 4.11 & 4.11 \\
\hline & Total & & & 10,298 & 10.40 & 17.52 & 108.20 & 19.02 \\
\hline \multicolumn{9}{|c|}{ 2. Livestock Expenses: } \\
\hline $550 \mathrm{P}$ & $\begin{array}{l}\text { Irchased Steers } \\
\text { Iiscellaneous Other Expenses }\end{array}$ & 195 & 2.02 & $\begin{array}{r}217,008 \\
24,739\end{array}$ & $\begin{array}{r}394.56 \\
44.98\end{array}$ & $\begin{array}{r}394.56 \\
44.98\end{array}$ & $\begin{array}{r}394.56 \\
44.98\end{array}$ & $\begin{array}{r}394.56 \\
44.98\end{array}$ \\
\hline & Total & & & 241,747 & 439.54 & 439.54 & 439.54 & 439.54 \\
\hline & TOTAL VARIABLE COST & & & 252,044 & 449.94 & 457.06 & 547.74 & 458.56 \\
\hline \multicolumn{9}{|c|}{ B. FIXED COSTS } \\
\hline & TOTAL FIXED COSTS & & & 21,855 & 39.74 & 39.74 & 39.74 & 39.74 \\
\hline & TOTAL COSTS & & & 273,899 & 489.67 & 496.80 & 587.47 & 498.30 \\
\hline C. NET & RANCH INCOME & & & 14,448 & 64.46 & -10.50 & -217.66 & 25.97 \\
\hline Proporti & n of Yearlings Purchased & & & & $68 \%$ & $25 \%$ & $7 \%$ & $100 \%$ \\
\hline
\end{tabular}

Adapted from medium-sized yearling stocker enterprise budgets presented in the New Mexico Livestock Cost and Return Series, 1996 (Torell et al. 1998 ). Assumes that 550 head of yearling steers are purchased. The feed costs of healing intoxicated animals are included in the appropriate expense categories. 